\title{
Editorial
}

\section{Apoptosis and the cell cycle: the p53 connection}

\author{
Caroline Choisy-Rossi ${ }^{1}$ and Elisheva Yonish-Rouach ${ }^{1,2}$ \\ 1 Laboratoire de Cancérogenèse Moléculaire, UMR 217 CEA-CNRS, DRR, DSV, \\ CEA, 92265 Fontenay-aux-Roses Cedex, France; tel: (+33)-1-46548944; fax: \\ (+33)-1-46548713; e-mail: eyonishr@armoise.saclay.cea.fr. \\ 2 corresponding author: Elisheva Yonish-Rouach
}

The p53 gene in its wild-type (wt) form is defined as a tumor suppressor gene. Indeed, mutations in p53 were found to occur in high frequency in most of the common types of human cancer (Hollstein et al, 1991). Stabilization and activation of p53 following a variety of signals, such as genotoxic insults, result in the execution of its biological activities. The best characterized activities of p53 are the induction of a cell growth arrest or of apoptosis.

Induction of a growth arrest by p53 was shown to depend on its ability to act as a sequence-specific transcriptional activator (Crook et al, 1994, Pietenpol et al, 1994). An important target gene in the growth arrest pathway is WAF1/CIP1 (El-Deiry et al, 1993; Harper et al, 1993). The protein product of this gene, p21, binds to cyclin-dependent kinases and inhibit their action, thereby blocking cell proliferation (Xiong et al, 1993). Mice lacking p21 were shown to be defective in the G1 checkpoint control (Brugarolas et al, 1995; Deng et al, 1995). However, the G1 checkpoint was only partially impaired, indicating that p21 does not play an exclusive role in this pathway.

The mechanism of p53-induced apoptosis is still not well characterized, and it appears that p53 may mediate apoptosis both through transcriptional activation-dependent and independent pathways.

Whether a cell would undergo growth arrest or apoptosis following p53 activation appears to depend on a variety of factors, such as environmental conditions and the cell type. As reviewed by Kasten and Giordano 1998 (see this issue), the loss of the tumor suppressor $\mathrm{pRb}$ function may contribute to p53-induced apoptosis: the activity of $\mathrm{pRb}$ and/or other pRb-related proteins was shown to be necessary for the induction of a G1 arrest by p53 following DNA damage (Demers et al, 1994; Hickman et al, 1994; Slebos et al, 1994; White et al, 1994), and pRb may have a protective effect on p53-induced apoptosis in some cells (Qin et al, 1994; Haupt et al, 1995) but not in all systems (Hsieh et al, 1997). In cells having a functional $p R b$, induction of p21 would lead to inactivation of cyclindependent kinases and therefore to inhibition of $\mathrm{pRb}$ phosphorylation. The hypophosphorylated $\mathrm{pRb}$ retains transcription factors of the E2F family, which are necessary for the G1/S transition, thus imposing a p53induced $\mathrm{G} 1$ arrest. In the absence of functional pRb, p21 will still be induced by p53 activation but cells will be unable to growth-arrest and may therefore be 'forced' to die through inappropriate cell proliferation signals by entering into S phase (Kasten and Giordano, 1998, see this issue). In this context, deregulated expression of E2F was shown to induce p53-mediated apoptosis (Qin et al, 1994; Shan and Lee 1994; Wu and Levine 1994; Almasan et al, 1995; Logan et al, 1995). E2F1-DP1 complex was reported to bind to and to induce p53, thereby overriding survival factors to induce apoptosis (Hiebert et al, 1995; O'Connor et al, 1995). Without both $\mathrm{Rb}$ and p53, E2F activation would stimulate cell proliferation and permit tumor formation, as was demonstrated by the development of retinal tumors in HPV E7 transgenic mice (Howes et al, 1994; Pan and Griep 1994). However, recent publications have demonstrated that E2F-1-induced apoptosis does not require transactivation and DNA synthesis and can occur in the absence of p53 (Hsieh et al, 1997; Nip et al, 1997; Phillips et al, 1997). Thus, the reported repression function of the $\mathrm{Rb}-\mathrm{E} 2 \mathrm{~F}-1$ complex (Zacksenhaus et al, 1996) may play an important role in regulation of apoptosis by these cell cycle proteins. Interestingly, $\mathrm{pRb}$ cleavage following caspases activation in several apoptotic pathways was observed (Kasten and Giordano 1998, see this issue, and references therein), suggesting that apoptosis may be incompatible with functional $\mathrm{Rb}$, and linking apoptosis to cell cycle.

Another link between cell death and regulation of cell proliferation is the c-Myc proto-oncogene. c-Myc plays a role as a positive regulator of cellular proliferation, but its activation can also result in apoptosis under certain environmental conditions such as serum deprivation or hypoxia (Evan et al, 1992; Graeber et al, 1996). Several studies have suggested a role for p53 in c-Myc-induced apoptosis upon serum withdrawal in fibroblasts (Hermeking and Eick, 1994; Wagner et al, 1994; Yu et al, 1997; Han et al, 1997). Using Rat-1 fibroblasts expressing a conditional c-Myc, Rupnow et al, 1998 (see this issue) demonstrate that cells expressing antisense p53 are more resistant to cMyc-induced apoptosis under hypoxic or low serum conditions. In this system, c-Myc activation also sensitized Rat-1 cells to radiation-induced apoptosis, and there again cells expressing antisense p53 were more resistant to apoptosis induced by the combined effect of c-Myc activation and $\gamma$-irradiation. Thus, p53 appears to be an important mediator of c-Myc-induced cell death under a variety of environmental stress signals.

The cellular response to p53 activation may depend not only on the cell type and factors such as Rb, as described above, but also on the level of p53 expression. Thus, high levels of p53 expression induced apoptosis while low levels induced cell cycle arrest in Saos-2 and H1299 cells (Chen et al, 1996). Using a similar approach of introducing a tetracycline-regulated inducible p53 expression into a p53null cell line of small cell lung carcinoma (SCLC), Adachi et 
al, 1998 (see this issue) assessed the effect of the level of p53 expression on these cells. Apoptosis was induced in SCLC cells by high levels of p53 expression, while low expression levels induced a G1 arrest. However, G1arrested cells underwent apoptosis after further cultivation. In agreement with previous reports in other cell types, p21 was induced by low and high levels of expression of p53 but it does not appear to play a role in p53-induced apoptosis (reviewed by Yonish-Rouach, 1996). Indeed, expression of exogenous p21 induced G1 arrest but not apoptosis in the SCLC cells. On the other hand, high levels of p53 down-regulated Bcl-2 expression in SCLC cells while Bax expression was not modified irrespective of p53 expression level. The authors suggest that p53-mediated apoptosis and $\mathrm{G} 1$ arrest depend on the level of p53 expression in SCLC cells, and that the relative high expression of Bax over low expression of $\mathrm{Bcl}-2$ at high level of p53 expression is involved in the induction of apoptosis. It is interesting to note that there is no G1 arrest at high level of p53 expression prior to the induction of apoptosis and concomitantly with down-regulation of $\mathrm{Bcl}-2$. Recent data provided evidence that Bcl-2 is yet another link between cell death and cell cycle regulation, since in addition to its anti-apoptotic function it can also restrain cell cycle entry (O'Reilly et al, 1996). Thus, the low expression of $\mathrm{Bcl}-2$ imposed by high level of p53 expression may play a role in escaping a $\mathrm{G} 1$ arrest.

Finally, the importance of p53-mediated apoptosis is demonstrated in an in vivo study by Reichel et al, 1998 (see this issue). Previous experiments have shown that a significant fraction of p53 null mice have developmental abnormalities, including profound neural-tube defects associated with overgrowth of neural tissue, and the affected embryos frequently undergo resorption (Armstrong et al, 1995; Sah et al, 1995). In the present study, Reichel et al, have identified a role for p53-dependent apoptosis in the regression of the hyaloid vasculature and tunica vasculosa lentis, thus providing further evidence for the importance of p53 in normal development. This study also demonstrates for the first time a role for p53 in postnatal development in remodelling of the developing eye.

\section{References}

Adachi J-i, Ookawa K, Kohno T, Tomizawa Y, Tsuchida S and Yokota J (1998) Phentopyic alterations of small cell lung carcinoma induced by different levels of wild-type p53 expression. Cell Death Differ. 5: 148-155

Almasan A, Yin Y, Kelly RE, Lee EY, Bradley A, Li W, Bertino JR and Wahl GM (1995) Deficiency of Retinoblastoma protein leads to inappropriate S-phase entry, activation of E2F-responsive genes, and apoptosis. Proc. Natl. Acad. Sci. USA 92: $5436-5440$

Armstrong JF, Kaufman MH, Harrison DJ and Clarke AR (1995) High-frequency developmental abnormalities in p53-deficient mice. Curr. Biol. 5: 931-936

Brugarolas J, Chandrasekaran C, Gordon JI, Beach D, Jacks T and Hannon JG (1995) Radiation-induced cell cycle arrest compromised by p21 deficiency. Nature 377: $552-557$

Chen X, Ko LJ, Jayaraman L and Prives C (1996) p53 levels, functional domains, and DNA damage determine the extent of the apoptotic response of tumor cells. Genes Dev. 10: 2438-2451

Crook T, Marston NJ, Sara EA and Vousden KH (1994) Transcriptional activation by p53 correlates with suppression of growth but not transformation. Cell 79: $817-$ 827
Demers GW, Foster SA, Halbert CL and Galloway DA (1994) Growth arrest by induction of p53 in DNA damaged keratinocytes is bypassed by human papillomavirus 16 E7. Proc. Natl. Acad. Sci. USA 91: 4382-4386

Deng C, Zhang P, Harrper JW, Elledge SJ and Leder P (1995) Mice lacking p21 CIP1/ WAF1 undergo normal development, but are defective in G1 checkpoint control. Cell 82: $675-684$

El-Deiry WS, Tokino T, Velculenscu VE, Levy DB, Parsons R, TrentJM, Lin D, Mercer EW, Kinzler KW and Vogelstein B (1993) WAF1, a potential mediator of p53 tumor suppression. Cell 71: 817-825

Evan GI, Wyllie AH, Gilbert CS, Littlewood TD, Land H, Brooks M, Waters CM, Penn LZand Hancock DD (1992) Induction of apoptosis in fibroblasts by c-myc protein. Cell 69: $119-128$

Graeber TG, Osmanian C, Jacks T, Houseman DE, Koch CJ, Lowe SW and Giaccia AJ (1996) Hypoxia-mediated selection of cells with diminished apoptotic potential in solid tumours. Nature 379: 88-91

Han JW, Dionne CA, Kedersha NL and Goldmacher VS (1997) p53 status affects the rate of the onset but not the overall extent of doxorubicin-induced cell death in rat1 fibroblasts constitutively expressing c-Myc. Cancer Res. 57: 176-182

Harper JW, Adami GR, Wei N, Keyomarsi K and Elledge SJ (1993) The p21 Cdkinteracting protein $\mathrm{Cip} 1$ is a potent inhibitor of $\mathrm{G} 1$ cyclin-dependent kinases. Cell 75: $805-816$

Haupt Y, Rowan S and Oren M (1995) p53-mediated apoptosis in HeLa cells can be overcome by excess pRb. Oncogene 10: 1563-1571

Hermeking $\mathrm{H}$ and Eick D (1994) Mediation of c-Myc-induced apoptosis by p53. Science 265: 2091-2093

Hickman ES, Picksley SM and Vousden KH (1994) Cells expressing HPV16 E7 continue cell cycle progression following DNA damage induced $\mathrm{p} 53$ activation. Oncogene 9: 2177-2181

Hiebert SW, Packham G, Strom DK, Haffner R, Oren M, Zambetti G and Cleveland JL (1995) E2F-1 DP-1 induces p53 and overrides survival factors to trigger apoptosis. Mol. Cell. Biol. 15: 6864-6874

Hollstein M, Sidranski D, Vogelstein B and Harris CC (1991) p53 mutations in human cancers. Science 253: 49-53

Howes KA, Ransom LN, Papermaster DS, Lasudry JGH, Albert DM and Windle JJ (1994) Analysis or retinoblastoma: alternative fates of photoreceptors expressing the HPV-16 E7 gene in the presence or absence of p53. Genes Dev. 8: $1300-1310$

Hsieh J-K, Fredersdor S, Kouzarides T, Martin K and Lu X (1997) E2F1-induced apoptosis requires DNA binding but not transactivation and is inhibited by the retinoblastoma protein through direct interaction. Genes Dev. 11: 1840-1852

Kasten MM and Giordano A (1998) pRb and the Cdks in apoptosis and the cell cycle. Cell Death Differ. 5: 132-140

Logan TJ, Evans DL, Mercer WE, Bjornsti MA and Hall DJ (1995) Expression of a deletion mutant of the E2F1 transcription factor in fibroblasts lengthens $S$ phase and increases sensitivity to $S$ phase-specific toxins. Cancer Res. 55: 28832891

Nip J, Strom DK, Fee BE, Zambetti G, Cleveland JL and Hiebert SW (1997) E2F-1 cooperates with topoisomerase II inhibition and DNA damage to selectively augment p53-independant apoptosis. Mol. Cell. Biol. 17: 1049-1056

O'Connor DJ, Lam EW, Griffin S, Zhong S, Leighton LC, Burbidge SA and Lu x (1995) Physical and functional interactions between p53 and cell cycle co-operating transcription factors, E2F1 and DP1. EMBO J. 14: 6184-6192

O'Reilly LA, Huang DC and Strasser A (1996) The cell death inhibitor Bcl-2 and its homologues influence control of cell cycle entry. EMBO J. 15: 6979-6990

Pan H and Griep AE (1994) Altered cell cycle regulation in the lens of HPV-16 E6 or E7 transgenic mice: implications for tumor suppressor gene function in development. Genes Dev. 8: 1285-1299

Phillips AC, Bates S, Ryan KM, Helin K and Vousden KH (1997) Inductionof DNA synthesis and apoptosis are separable functions of E2F-1. Genes Dev. 11: $1853-1863$

Pietenpol JA, Tokino T, Thiagalingam S, El-Deiry WS, Kinzler KW and Vogelstein B (1994) Seuqence-specific transcriptional activation is essential for growth suppression by p53. Proc. Natl. Acad. Sci. USA 91: 1998-2002

Qin XQ, Livingston DM, Kaelin WG and Adams PD (1994) Deregulated transcription factor E2F-1 expression leads to S-phase entry and p53-mediated apoptosis. Proc. Natl. Acad. Sci. USA 91: 10918-10922

Reichel MB, Ali RR, D'Esposito F, Clarke AR, Luthert PJ, Battacharya SS and Hunt DM (1998) High frequency of persistent hyperplastic primary vitreous and cataracts in p53-deficient mice. Cell Death Differ. 5: 156-162 
Rupnow BA, Alarcon RM, Giaccia AJ and Knox SJ (1998) p53 mediates apoptosis induced by c-Myc activation in hypoxic or gamma irradiated fibroblasts. Cell Death Differ. 5: 141-147

Sah VP, Attardi LD, Mulligan GJ, Williams BO, Bronson RT and Jacks T (1995) A subset of p53-deficient embryos exhibit exencephaly. Nat. Genet. 10: 175-180

Shan B and Lee WH (1994) Deregulated expression of E2F-1 induces S-phase entry and leads to apoptosis. Mol. Cell. Biol. 14: $8166-8173$

Slebos RJ, Lee MH, PlunkettBS, Kessis TD, Williams BO, Jacks T, Hedrick L, Kastan MB and Cho KR (1994) p53-dependent G1 arrest involves pRB-related proteins and is disrupted by the human papillomavirus 16 E7 oncoprotein. Proc. Natl. Acad. Sci. USA 91: $5320-5324$

Wagner AJ, Kokontis JM and Hay N (1994) Myc-mediated apoptosis requires wildtype p53 in a manner independent of cell cycle arrest and the ability of p53 to induce p21 waf1/cip1. Genes Dev. 8: 2817-2830

White AE, Livanos EM and TIsty TD (1994) Differential disruption of genomic integrity and cell cycle regulation in normal human fibroblasts by the HPV oncoproteins. Genes Dev.8: 666-677
Wu X and Levine AJ (1994) p53 and E2F-1 cooperate to mediate apoptosis. Proc. Natl. Acad. Sci. USA 91:3602-3606

Xiong Y, Hannon GJ, Zhang H, Casso D, Kobayashi R and Beach D (1993) p21 is a universal inhibitor of cyclin kinases. Nature 366: 701-704

Yonish-RouachE(1996) The p53 tumour suppressor gene: a mediator of a G1 growth arrest and of apoptosis. Experientia 52: 1001-1007

Yu K, Ravera CP, Chen YN and McMahon G (1997) Regulation of Myc-dependent apoptosis by p53, c-Jun $\mathrm{N}$-terminal kinases/stress-activated protein kinases, and Mdm-2. Cell Growth Differ. 8: 731-742

Zacksenhaus E, Jiang Z, Phillips RA and Gallie B (1996) Dual mechanisms of repression of E2F1 activity by the retinoblastoma gene product. EMBO J. 15 $5917-5927$ 